\title{
Application and the Implementation Organs of Alternative Measures in Macedonia
}

\author{
Adrian Leka \\ PhD Candidate, Faculty of Law, University of Shkoder "Luigj Gurakuqi" \\ Shkoder, Albania, 4001 \\ Email: leka-ad@live.com
}

Doi:10.5901/mjss.2014.v5n16p78

\begin{abstract}
The alternative measures are useful sanctions for those who commit the penal acts and for the whole society. The present better chances and more favourable on the realisation of rights and personal freedoms and to the functioning of democratic society. Until now the alternative sanctions are known very well since there exist states that had them since in earlier times and have commenced to apply them.On the basis of a critical viewpoint regarding the way how they are applied in Macedonia, analysing the statistics of the Statistical Institution, it is concluded that Macedonia even though has foreseen them in the penal Code since in 2004, has not yet started their application. Until now regarding the offenses with a low social risk have been pronounced only two types of alternative measures such as: conditional sentence and the judicial remark while the other types have not been applied so far. The Criminal policy should be oriented in two directions: - in one direction should be started as soon as possible to apply the foreseen sanctions which are part of the law, and - on the other side besides the new types of alternative measures which are not yet part of it yet, but the other states have them and they do have an effect on them, and it is thought that they would have such impact even in our states. With alternative measures is enabled a better respecting of freedoms and human rights and the benefit is double, since there benefits the convicted person but in the meantime the state itself benefits as well. Macedonia in order to have success in their execution needs to have a coordination of law courts, should appeal to those that apply more often the protective supervision.,forming special teams which is are ready to perform their duties, there should be found good material means with which would be constructed a more effective,preventative, measures should be taken to prevent criminality, there is needed training of lawyers in that direction and to be asked that where it is possible the defined criteria should be applied. The alternative measures are functional measures, they bring positive impact and are very important,therefore it is indispensible to start their application in practice, as a very effective opportunity to a normal, quiet and secure life for all citizens.
\end{abstract}

\section{Fundamental Principles}

Respecting the basic principles is very important because only through them is made possible fair functioning of justice and law. European Rules provide enough conditions and principles that must be respected in imposing such measures, and they are:

- Alternative measures have priority over measures to detention or jail.

- Their implementation should be done without discrimination based on age, gender, race, religion, national or social affiliation.

- Determination must be done based on law.

- Be corresponding to the penal offense

- Consideration of the needs for rehabilitation of offenders, protection of society and the interests of the victim.

As provided for in international instruments, alternative measures are defined with very broad notion and therefore contain different sanctions and the criminal proceedings may be submitted at any stage if the indictment, the trial, judgment or prison.

\section{Factors which Influenced the Acceptance of Alternative Measures}

States which envisaged in their codes alternative measures considered necessary to justify the factors which justify their application.

- Their cost (in European countries implementing alternative sentencing is up to 20 times cheaper than imprisonment)

- The problem with prison overcrowding 
- Short-term Prisoning

- Success in the execution of imposed sentences

\section{The Distinction of the Authors of Penal Acts Considering the Gender Aspect}

The Authors of penal acts / violations besides being distinct by the age can be distinguished as well by gender, since based in various international statistics males dominate largely. There are such cases as well when females are present in the statistics as authors of the same penal acts but up to know their presence in such acts is $7-8 \%$, which is a big difference between males and females and it is as such almost like all the offenses. Based on the statistics of the year 2004 from the total of 8097 convicted persons, for various offenses 7634 are males, while 463 are females. During 2005 from 8845 convicted persons 574 are females. While during 2005 from 8845 convicted people 576 are females, while during 2006 from 9280 convicted people 560 are females.

\section{The Role of the Delinquent in the Announcement of Alternative Measures}

The convicted people play a main role in the administration of alternatives which means that in most cases depending on the way they behave depends a lot the application of alternative measures. Those for which should be given those penal sanctions should firstly respect the rules that are foreseen by the prison orders and the legal acts.

He/she should behave in compliance with the social, moral and legal norms of the location where he lives or works. That person first should testify that he has became capable to go back to normal life, but now changed, re-educated and willing as a correct citizen. As main terms that depend on the author that has committed the penal act and his behaviour after he has committed the offense.

Therefore, another term and that one, that the court should form the conviction that that person in the future will not repeat the offense or the violation.

\section{The Victims Role in the Announcement of the Alternative Measure}

What is needed to them is to provide assistance and clarification that due to the fact that the author will be free again they will still have protection and care offered by the competent organs and that also the release process of the authors of such penal acts should be very well leaded and supervised by professional institutions.

\section{The Role of the Probation Body in the Alternative Measures}

The probation body is an accountable organ for the execution of sentences, alternative measures, supervision and resettlement, reintegration, rehabilitation and the improvement of all persons that have committed offences at a certain moment punishable according to the Penal Code.

This organ is an important factor in the administration of alternative measures since it performs many obligations related to the author, knows very well his personality therefore this organ can propose to the court which type of alternative measure is most suitable to realise the purpose of the alternative measure.

\section{The Law Courts Role in the Alternative Measures}

The courts are the single competent organs which can grant the alternative sentences the same way as they give all the types of other condemnations. They in compliance with the law should provide several measures and alternative sanctions such as the suspension of the sentence execution. It is a fact that even during giving of the condemnations there might exist dilemmas and problems but it is very reasonable to enounce such convictions rather than continuing with the old practice. The positive impact and the application of the alternative measures depends on the speed of the actions carried out by the court.

\section{The Role of Police in Alternative Measures}

The police is a competent organ for the criminality prevention since it deals with the discovery of the penal acts and their authors. It has a very crucial role even during the administration of the alternatives since the police should first recognise the convicted person in the station or the place where he works or acts, to recognise the other people of the district who 
have got criminal files or that manifest criminal actions. The police observes and controls the convicted person so without their collaboration these measures cannot be executed. The police works with the convicted people and the centre for social work and gives directives for the execution of penal sanctions even at the court.

\section{The Obstacles in the Implementation of Alternative Measures}

Since in 2004 the alternative measures are foreseen in the Penal Code but these changes even though have come in power have not started to be implemented in practice.

The main obstacles are:

- The court first has established very wide practice of the granting of the conditional sentence and the judicial remark therefore the other alternative measures carefully considered. What should be done regarding their enunciation, the court first has to deal with the training of the lawyers and overcoming the obstacles and doubts.

- The lack of a very high level of professionalism to observe and check the practical application of measures, since all the people that take part in the determination enunciation and their application requires a very high level of professionalism.

The concept of professional staff engaged in the application of alternative measures implies a sufficient number of professional staff due to the number of alternative measures as well as the number of people against whom are taken these measures.

- The lack of specialised institutions such as social institutions in commune level consisting of professional people such as psychologists, professors, sociologists etc

- Lack of coordination and collaboration between the institutions for their application

- There is needed skills and training of supervising staff, since the convicted people with alternative measures should be supervised by a special institution which is able that during the time should know what is happening with the convicted person and this will be achieved only if the supervising staff will be trained. The trained staff is willing to face the difficulties during the supervision, control and prevention of penal acts.

- Consultations at multinational level should take place regarding the shortcomings and priorities in other states, since there are states that have applied such measures much earlier than us so there is the need to organise conferences and meetings at multinational level where there should be discussed in detail the difficulties that they have met while executing such measures.

\section{Elaboration on Alternative Measures in Macedonia}

The interest to study the alternative measures has been very necessary. In Macedonia a project has been organised under the care of the Ministry of Justice, Foundation Open Social Institute and the Council on the delinquency prevention for Juveniles in 2003/04

The aim of this project has been to better know the alternative measures, their practical application and identifying the sectors to realise them. In this case have participated several lawyers, public prosecutors, employees of social centres, employees from punishing rehabilitating centres, police representatives, and from Ministry of Justice, from the Sector of penal sanctions execution and representatives from local government.

Regarding their attitudes about the alternative measures there has been conducted a survey with direct questions and the respondents have responded as follows:

- Do you know the system of alternative measures?

The majority answered yes.

- What are their specific characteristics?

Escape from suffering the sentence in prison, joining the world's trends, special preventions, humanisation of penal sanctions, reduction of overpopulated prisons.

- Which alternative measures are known best?

Home prison, victims reward,conditional sentence, working at public interest, judicial remark,semi-liberty.

- Which are the most acceptable alternative measures?

The work at public interest, conditional sentence, victim's reward,home prison

- According to the weight of the offense with which type of conviction you would replace it?

The majority responded with the imprisonment up to 1 year,respectively up to 3 years or less for the penal acts 
up to 5 years.

- Towards whom you would have enunciated the alternative measures?

The majority were for the ones of have committed an offence for the first time or for those offences that have taken place due to the lack of care, but only e few were for the recidivists.

- According to the age-groups to whom you would give alternative measures?

34 respondents have defined the age 21-30, while 22 respondents to the age-group 60 years old.

- What other obligations should be foreseen?

Most of respondents were community general work, keeping contacts with the in charge of the social work centre, damage compensation, the visit of educational centres attend group therapy aiming to avoid the problems related to psychological character etc.

- Why the lawyers up to now have never given such measures besides conditional sentence and the judicial remark?

Reasons: the lack of conditions for supervision and control, lack of conviction to realise it, lack of coordination and collaboration between the institutions to apply them.

- Which are the elements that a lawyer should know in the cases when an alternative measure is given?

Each lawyer should know well the personality of the author that has committed the penal act that have to do with the age., individual characteristics, family status and the most important, pangs of conscience.

- How would the alternative measures impact the state of the victim?

The majority have the opinion that the alternative measures will improve their state, while a small number think that they would aggravate their state.

\section{References}

Arnaudovski L, Bugjarova G, Celevski D, Manev L, Evropski pravila za alternativnite merki, Shkup, 2004

Kambovski V. Criminal Code (general part) Shkup 2004

Kanavqev M. Kriviqen zakonik na R. Makedonija, Shkup 2004

Taseva S. Kriviqen zakonik na R. Makedonija, Shkup 2004

Evropski pravila za alternativnite sakcii i merki primenuvani vo zaednicata revistë nr.1 Shkup (1998)

Storiteli na kriviqni dela, Drzhaven Zavod za Statistika, Shkup 2007

Storiteli na kriviqni dela, Drzhaven Zavod za Statistika, Shkup 2006

Storiteli na kriviqni dela, Drzhaven Zavod za Statistika, Shkup 2005

New Criminal Code of Republic of Macedonia, ( Official Newspaper ) Shkup 2004 